\title{
The Legalization Process of Persons of Indonesian Descents (PIDS) in Mindanao and Their Reasons to Remain in Mindanao after Nationality Awarding
}

\author{
Putrie Agusti Saleha ${ }^{1}$, Benny Teh Cheng Guan ${ }^{2}$ \\ (putrie.saleha@student.usm.my ${ }^{1}$, ben@usm.my²) \\ School of Social Sciences, Universiti Sains Malaysia (USM) ${ }^{1,2}$
}

\begin{abstract}
This research aims are to identify the effects of legalization process for the Persons of Indonesian Descent living in Mindanao, Philippines and to investigate the reasons of the Registered Indonesian Nationals (RINs) staying in Mindanao after the nationality awarding. In the 1870 s, PIDs' ancestors crossed the sea using a traditional boat to reach the Philippines from the North Sulawesi province to Balut Island close to Sarangani Province in Mindanao. However, after both countries gain their independence, specific laws were applied regarding the legal documents and caused the children born with stateless status. The interview happened in 2016 and 2019 shows the legalization process has given various good impacts to the lives of PIDs. However, after they became a RINs, some of them continue their life in foreign land due to unrecognized relatives living in Indonesia and better income opportunity in Mindanao areas.
\end{abstract}

Keywords: Legalization, statelessness, stateless person, Persons of Indonesian Descents (PIDs), Registered Indonesian Nationals (RINs).

\section{Introduction}

The issue of statelessness in current times is still ongoing. Many people are still struggling to get their nationality in some parts of the world to have the rights of a country. This issue even has been understood as one big challenge for the international community [1]. Referring to The World's Stateless book, stateless is "Someone who is not considered as a national by any state under the operation of its law" [2]. People with stateless status could not obtain or enjoy any rights or duties or protection from a particular state. A group of people commonly abused them to fulfill their means. The majority of stateless persons are at high risk of discrimination, human rights abuses, and even persecution. Most stateless people will become internally displaced persons (IDPs), asylum seekers, and refugees [2]. One of the reasons people have become stateless is because of the war in their previous country.

Many of them then sailed a boat or risked their lives to cross the border to obtain asylum from developed countries. This situation has occurred in some countries, such as Palestine, Syria, Myanmar (Rohingya), and other countries in conflict. They are trying to get protection from the nearest states or countries to have a better future. However, someone can also become stateless in a country where they were born and lived for their entire lives. An example of this is the Indonesian diaspora living in the southern part of the Philippines or Mindanao [3]. 


\section{What are PIDs?}

Person of Indonesian Descent (PIDs) is a phrase used to recognize the Indonesian diaspora living in the southern part of the Philippines. These people were threatened to become stateless because they do not have legal documents to prove their belongings. There are few perspectives on the historical background of the arrival of the PIDs in Mindanao. However, these people have been living without legal documents for four generations to this day [4], and it has been a challenging and demanding life for them to live in. This phenomenon has begun to rise since the PIDs' ancestors migrated from northern Sulawesi (mostly from Sangir and Marore Island) to some parts of the Philippines, such as Balut Island Sarangani, around the 1870s [5]. As the former Immigration Attaché of the Indonesian Consulate in Davao City, Agus Abdul Majid, stated, the migration between these two countries occurred quickly during that time due to the close border.

Traditionally, they had migrated from Indonesia, sailed a boat across the ocean, and arrived at Balut Island, Glan, and other places. Migration is not only done by the PIDs' ancestors [6]. The Filipinos who stayed in Glan, Sarangani province, often did the same thing. In the beginning, ancestral migration from these PIDs aims to have better trading activities. They used to sell products from their hometown to Mindanao, and they are going to bring another thing from Mindanao to be sold in their hometown. The Filipinos from Mindanao also visited North Sulawesi and did the same thing as them, and the cultural exchange took place as a result of this activity [5].

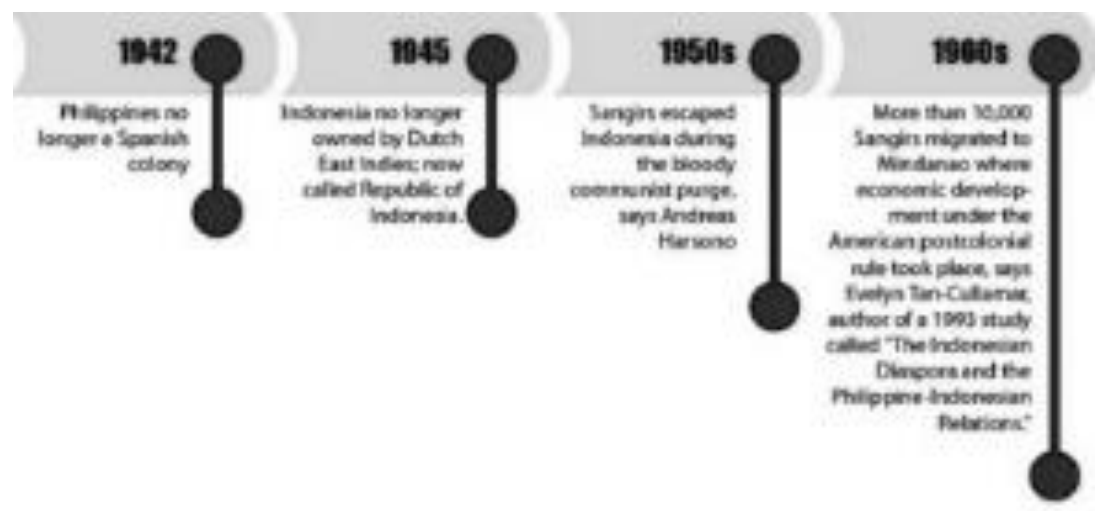

Image 1. The PIDs migration process from Indonesia to the Philippines

By that time, these people did not feel any insecurities about their nationality because these countries were under colonization. Unfortunately, between 1945 and 1946, Indonesia gained independence from Japan, and the Philippines gained independence from the United States. The problem of statelessness for the Sangers started when both countries need to create adjustments for their countries, including the Sangers [7]. These people need to decide whether they want to be Indonesian or Filipino. However, regarding the citizenship law of the Republic of Indonesia 1958 , number 62 and renewed by the law of 2006, number 12 chapter 3 article 19 verse 2 stated 
that any person who would like to register as an Indonesian citizen or descent need to stay at least five years in sequence or ten years non-sequential [8]. However, this law seemed to solve the Sangers or the Indonesian descendants since they were unwilling to come back to Indonesia and stay for that long time [9].

\section{The Cooperation among UNHCR, Indonesian Government and Philippines Government}

In 1995, the first Joint Commission among the Indonesian Government and the Philippines government was launched, and the second Joint Commission was held in 1998. As part of the Joint Commissions deal, both governments have decided to create an Alien Certificate of Registration (ACR) for these PIDs as their identity card. To gain the ACR, the PIDs need to pay around 410.00 Philippines Peso for those above 14 years old, P210.00 for those below 14 years old, and P160 for the annual extending fee [4]. The benefit of having this ACR for these PIDs, they gain the residence permit to stay in the Philippines legally, the ability to travel freely, the ability to legalize their work contract for those who worked in the companies or factories, and efficiently manage the permissions for their business license to the local government offices, pursuing studies and application for travel documents [4]. However, some PIDs could still not get the ACR and live with illegal status because they lived in poverty that they cannot afford to pay for the ACR registration and the transport to come to the immigration office. With such conditions, the PIDs force to work as cheap labor in fishery factories, coconut plantations, or house assistants to support their families [9]. Most of them worked in the fishery factories using their ACR as their only legal document [10]. However, these workers sometimes were used by the owner of factories to catch the fish near Indonesia's sea border. When the armed Indonesian Navy arrests them for illegal fishing, the factory owner will not take any responsibility in this case [11].

Looking at the matter that these people have faced, the United Nations High Commissioner for Refugees (UNHCR) held a meeting with the Indonesian Government and 8 Philippines government to find a solution for the PIDs and end the statelessness status. Since 2011, these three actors have been working to end Mindanao's statelessness, especially for the Indonesian descendants who lived without supporting documents their entire life. After the joint meeting, they came out with a solution, a pilot project to award the PIDs with the nationality they desired to have, whether Indonesian or Filipino [9]. The Philippines' Department of Justice - Refugees and Stateless Persons Unit (DOJ-RSPPU) took the lead during the project and the Bureau of Immigration, Public Attorney's Office, Indonesian Consulate, and UNHCR Philippines. Each agency has its specific roles and jobs to support Persons of Indonesian Descent [12]. By 2016, before the nationality awarding process began, around 8745 persons of Indonesian descent registered from different areas of Mindanao [7].

This research will use the legalization concept and support push and pull factor theory to collect the final results of how the legalization process affects PIDs' lives. The reasons for RINs remain residing in Mindanao areas after nationality awarding. The methodology proposed by the writer is data collection by using an online interview with the related people, officials, organizations, and other related stakeholders, and then some numbers of the online survey might be needed as well to collect different input from the RINs. After all those data collection processes, the data will be analyzed to gain the final results. 


\section{Research Methods}

The mission started with the registration system. During the registration system, the persons of Indonesian descent will follow some steps that are obligate to be followed by Indonesian descent. After getting the registration systems results and following all the steps, the actors will find the permanent solution for Indonesian descent. The permanent results will be based on the options chosen by the persons of Indonesian descent at the registration.

\section{The Registration System}

The registration is done by a joint team consisting of Indonesian Consulate representatives in Davao City, the Department of Justice, Bureau of Immigration, Public Attorney's Office, UNHCR, and NGOs (Pasali). Before the implementation of the registration process, the field team of UNHCR and Pasali will stage the community preparation to have a meeting with the LGU (Local Government Unit) to prepare for the registration place and spread the invitation to the PIDs with the help of the Liaison Officer (LO) of Consulate General in Davao City [13].

\section{Step 1: Orientation}

Every person of Indonesian descent who comes (both carry the invitation or not) to the registration place will be placed in groups to attend a brief orientation about the necessary documents and details of activities in the registration process to follow all the stages of registration well [9].

\section{Step 2: Reception}

At this stage, each person of Indonesian descent will be given a serial number and booklet/information regarding citizens' rights and obligations. At this stage, they also will be given some facilitations that might be helpful for them, especially for the special assistance (such as interpreters, children and the elderly, persons with disabilities) [9].

\section{Step 3: Data Verification}

At this stage, each PID must show their documents to the joint team's representatives, whatever they have (passports, birth certificates, identity cards, voter cards, or others.). Each paper will be checked for authenticity by the verifiers from the Joint Team representatives and short interviews related to the documents [9].

\section{Step 4: Registration}

At this stage, every person of Indonesian descents' data, family (father, mother, wife/husband, and children), their origins, and occupation will be input into PIDs' registration system. At this stage, the joint team was also taking the biometric data (photograph and fingerprints) and scanning the documents that own by the persons of Indonesian descent into the database of the registration system of PIDs [9].

\section{Step 5: Counseling}

At this stage, the person of Indonesian descents is allowed to consult with the Lawyer from the Public Attorney's Office and with the Indonesian Consulate representatives in Davao City to understand their citizenship status under the Act and the rules applied in Indonesia or the 
Philippines, to gain a complete understanding of citizenship countries' rights and responsibilities (both Indonesia and the Philippines) [9].

After the registration processes, the most crucial plan is the solution mission for Indonesian descendants. In this preparation for the permanent solution mission, the Philippines government has done some meetings with some agencies related to the internal of Philippines government, and also a bilateral meeting between the Philippines Department of Justice and the delegates of Indonesia's Ministry of Laws and Human Rights to establish the joint policy which will be permanent to determine the clarity of the nationality status of the PIDs [14].

\section{The Permanent Solutions for PIDs}

The permanent solutions and the follow-up actions for the persons of Indonesian descents offered by the actors can be described as follows:

\begin{tabular}{|c|c|c|c|}
\hline Status & Options & $\begin{array}{l}\text { Follow-up } \\
\text { Actions }\end{array}$ & Institutions \\
\hline \multirow[t]{4}{*}{$\begin{array}{l}\text { WNI } \\
\text { (Indonesian) }\end{array}$} & \multirow[t]{4}{*}{$\begin{array}{l}\text { Stay in } \\
\text { Mindanao }\end{array}$} & Nationality Clarity & $\begin{array}{l}\text { The ministry of Laws and Human Rights } \\
\text { Republic of Indonesia \& Indonesian Consulate } \\
\text { in Davao City }\end{array}$ \\
\hline & & $\begin{array}{l}\text { Passports granting, } \\
\text { Regarding the } \\
\text { PNBP, the passport } \\
\text { needs to get the } \\
\text { exemption. }\end{array}$ & $\begin{array}{l}\text { Indonesian Consulate in Davao City/The } \\
\text { immigration of the ministry of Finance }\end{array}$ \\
\hline & & $\begin{array}{l}\text { The clarity of } \\
\text { Philippines } \\
\text { immigration } \\
\text { permission }\end{array}$ & Philippines Bureau of Immigration \\
\hline & & Residing Visa & DOJ/Bureau of Immigration \\
\hline \multirow[t]{3}{*}{$\begin{array}{l}\text { WNI } \\
\text { (Indonesian) }\end{array}$} & \multirow[t]{3}{*}{$\begin{array}{l}\text { Return to } \\
\text { Indonesia }\end{array}$} & $\begin{array}{l}\text { Confirmation } \\
\text { granting of the } \\
\text { Indonesian } \\
\text { nationality }\end{array}$ & $\begin{array}{l}\text { The ministry of laws and Human rights of } \\
\text { Republic Indonesia \& Indonesian Consulate in } \\
\text { Davao City }\end{array}$ \\
\hline & & $\begin{array}{l}\text { SPLP Granting, } \\
\text { Regarding the } \\
\text { PNBP SPLP need } \\
\text { to give exemption. }\end{array}$ & $\begin{array}{l}\text { Indonesian Consulate in Davao City/The } \\
\text { immigration of the ministry of Finance }\end{array}$ \\
\hline & & $\begin{array}{l}\text { Returning } \\
\text { process/repatriation }\end{array}$ & $\begin{array}{l}\text { Indonesian Consulate in Davao City/Central } \\
\text { government }\end{array}$ \\
\hline
\end{tabular}




\begin{tabular}{|l|l|l|l|}
\hline & & $\begin{array}{l}\text { Living place and } \\
\text { the source of } \\
\text { livelihood in } \\
\text { Indonesia }\end{array}$ & $\begin{array}{l}\text { The ministry of village, PDT and } \\
\text { transmigration, BNPP North Sulawesi }\end{array}$ \\
\hline $\begin{array}{l}\text { WNF } \\
\text { (Philippines) }\end{array}$ & $\begin{array}{l}\text { Settled in } \\
\text { Mindanao }\end{array}$ & $\begin{array}{l}\text { The withdrawing of } \\
\text { the Indonesian } \\
\text { nationality and all } \\
\text { the documents } \\
\text { related to republic } \\
\text { of Indonesia }\end{array}$ & $\begin{array}{l}\text { Indonesian Consulate in Davao City/ The } \\
\text { ministry of laws and Human rights of Republic } \\
\text { Indonesia }\end{array}$ \\
\cline { 2 - 3 } & $\begin{array}{l}\text { The confirmation } \\
\text { of Philippines } \\
\text { nationality }\end{array}$ & Philippines government \\
\hline
\end{tabular}

Source: [9]

Table 1. The Permanent Solutions and Follow up Actions

After all the nationality awarding processes for the Persons of Indonesian Descendants in the Southern part of Mindanao, the Philippines, they are currently known as Registered Indonesian Nationals (RINs). However, there are only a few numbers of RINs that return home to Indonesia [15]. Most of them who chose to be Indonesian prefer to stay and continue their life in Southern Mindanao. When the writer was visiting southern Mindanao back in 2016, these RINs that the writer met mentioned their willingness to go home to Indonesia since some never had any chance to see their hometown since they were born. They would like to return and spend their lives in the place they can call their 'home'. However, they could not return to Indonesia due to a lack of legal documents such as passports and identity cards or other evidence that proves they belong to Indonesia or the Philippines. Nevertheless, there are around 2435 Registered Indonesian Nationals still residing in some areas of Mindanao [7].

\section{Results and Discussion}

\section{The Impact of Legalization Process on the PIDs Life}

Before the joint mission among UNHCR, the Indonesian Government, and the Philippines government to end the statelessness, the life of the People of Indonesian Descent was very concerning. One of the issues is when the persons of Indonesian descent in Mindanao sometimes also become an object for some actions of state or regional actors during the election time, such as a state or regional actor letting the persons of Indonesian descent participate in the election to win in local elections. Most of these actors treat the persons of Indonesian descents invariably depends on how dominant the persons of Indonesian descents respond to them [16]. The positive impacts that someone could get from having a nationality include gaining much support and easy access to the Government's facilities. Then, good quality of education, health facilities, and access to a job field. The important thing is that someone will get his right to be protected by the country's law [15].

After the legalization process ended, 2435 out of 8745 people of Indonesian descent chose to remain living in Mindanao [7]. They decided to stay in Mindanao because they married the locals and have built their family there, having better income instead of working in Indonesia, have no relation did to their relatives in Indonesia. It is hard to start to build a new life in a place 
they have never been before. Nevertheless, they still choose to be Indonesian because that is the only thing they have from their ancestors and to show love to the place where they came from [15].

\section{Conclusion}

The Persons of Indonesian descent were identified after the Independence Day of Indonesia and the Philippines. Most of them came from the North Sulawesi province in Indonesia. They sailed the traditional boat and risked their lives to go to Balut island, which is the nearest place in the Philippines' territory from Indonesia. Since their arrival, inter-marriage between the PIDs and residents happened. Their kids were threatened to be stateless since the parents did not have any legal documents that show their nationality. To stop them from being stateless, UNHCR, the Indonesian Government, and the Philippines government are working together to award these people with race which they are desire to have. The Philippines ' Government will manage those who choose to be Filipino. The PIDs who decided to be Indonesian (RINs) will be under the Indonesian consulate's supervision, and gradually they will return to Indonesia. Nevertheless, not all these RINs wish to return to Indonesia; 2435 of the RINs chose to stay in the Mindanao areas. From the previous visit to Glan and General Santos City, where most of the RINs reside, the common reasons are because their families are currently living in Mindanao, and they have a better job with a better income than Indonesia.

\section{References}

[1] H. L. Michelle Foster, "Stateless as a Human Right Issue: A Concept Whose Time Has Come," Int. J. Refug. Law, p. 564, 2016.

[2] I. on S. and Inclusion, The World's Stateless. Wolf Legal Publishers, 2014.

[3] E. S. S. Alam, Menyibak Tabir WNI, Second Edi. Davao City: Konsulat Jenderal Republik Indonesia, Davao City, Filipina, 2006.

[4] E. S. S. Alam, Menyibak Tabir WNI, Second Edi. Davao City: Konsulat Jenderal Republik Indonesia, Davao City, Filipina, 2006.

[5] P. A. Saleha, "The Cooperation among UNHCR, Indonesian Government, and Philippines Government in Managing the Stateless Status Issue of PIDs in Mindanao," Universitas Muhammadiyah Yogyakarta, 2017.

[6] A. A. Majid, "History of PIDs in Mindanao," 2016.

[7] H. R. T. SJAHPUTRA, “A DILEMMA BETWEEN LEGALITY AND WELFARE: A CASE STUDY: REGISTERED INDONESIAN NATIONALITY IN GLAN, SOUTHERN MINDANAO THE PHILIPPINES," Universitas Muhammadiyah Yogyakarta, 2019.

[8] D. RI, “LAW OF THE REPUBLIC OF INDONESIA NUMBER 12, YEAR 2006 ON CITIZENSHIP OF THE REP . OF INDONESIA IN THE NAME OF GOD ALMIGHTY," no. 12, 2006.

[9] A. A. Majid, "Registrasi Dan Konfirmasi Kewarganegaraan," 2016.

[10] A. Rahman, "PIDs in General Santos," 2016.

[11] Ridwan, "PIDs in General Santos," 2016.

[12] F. Tanggol, "Philippine and Indonesian Governments work together to end 
statelessness in Mindanao," 2017. https://www.unhcr.org/ph/11753-philippineindonesian-governments-work-together-end-statelessness-mindanao.html.

[13] P. P. Foundation, “Mapping Stateless Indonesians in Mindanao," 2012.

https://issuu.com/manchamancha/docs/mapping_indonesians_pasali_philippines_unhc r.

[14] A. Ariwibowo, "KJRI Davao promosikan perlindungan WNI," 2016. https://www.antaranews.com/berita/599823/kjri-davao-promosikan-perlindungan-wni.

[15] E. R. Yuliarti, "The Return of RINs to Indonesia," 2019.

[16] R. Talampas, "Indonesian Diaspora Identity Construction in a Southern Mindanao Border Crossing," pp. 136-168, 2015. 